\title{
How to be a choni: Tutorial videos, class and gender in spain's economic recession
}

\begin{abstract}
This article examines the construction of the choni (chavette) character through ironic and popular beauty tutorials created by Spanish vloggers and their connection with the economic recession in Spnin. Our main objective is to discover the use of gender, cultural and class markers in this process and their relation to the dynamics of self-construction and self-differentiation existent on YouTube. In order to identify these characteristics, we are going to use a semiotic and Foucauldian discourse analysis based on the cultural approach to the chav phenomenon in the United Kingdom. The findings from our research illustrate how the figure of the choni is defined by the process of racialization and sexualization and by a lack of cultural competence.
\end{abstract}

\section{INTRODUCTION}

In narratives about the economic crisis in the United Kingdom, the demonization of the figure of the chav as a working-class agent has attracted considerable interest due to its central position in the social, political and media discourses (Jones 2012). Furthermore, the investigation around the representation of the chav in the media and in digital forums has achieved some important contributions in the academic field of Cultural Studies in England,

\section{Keywords}

choni

chavette

YouTube

self-construction

beauty tutorial

social class 
but few researchers have addressed the problem of the young underclass from this perspective in Spain, where the rate of young unemployment is one of the highest inside Europe and where the share of youths neither in employment, education nor training (NEET) 'ranks near the top of the OECD, surpassed only in Mexico, Greece and Italy' (Álvarez 2015). The construction of the young Spanish 'ni-ni', the Spanish version of the NEET, in opposition to the young entrepreneur and based on their lack of employment and education is for Serrano and Martín (2017) part of a new work ethic, marked by the individualization of social problems and the redistribution of responsibilities also present in theState's employability programmes.

This specific area of Cultural Studies has been neglected to the point of the absence of a clear definition of the cultural stereotypes related to the young underclass, the feminine choni and the masculine cani. This lack of definition is offset by their omnipresence in the media through the lifestyle sections of the newspapers (Cerro 2014; Ríos 2014; Trapiello 2009), and especially in celebrity journalism through the figure of the 'Celebrity Chav' (Tyler and Bennett 2009) such as Belén Esteban, Ylenia Padilla, Oriana Marzoli and Amanda Rodriguez Morales. Perhaps the most privileged medium for this figure is television. The choni appears to be the perfect social stereotype for young underclass women created by the neo- and hyper-television era (Eco 1983; Scolari 2008) with their populist agenda of transforming the spectator in the spectacle through reality and talk shows. In this way, the choni became the protagonist of reality shows based upon the spectacularization of the social differences, as in Las Joyas de la Corona (2010, Spain: Zeppelin), a Spanish adaptation of Flavor of Love: Charm School (2007, USA: VH1), or as in Princesas del barrio (2011, Spain: Eyeworks Cuatrocabezas). The choni is also the female protagonist of TV shows focused on exploitation and moral condemnation of youth population, as in Gandia Shore (2012-2013, Spain: Magnolia TV) or Mujeres y hombres y viceversa (2008-present, Spain: Bulldog Producciones) Her presence in fiction is relevant in TV series such as Aida (2005-2014, Spain: Globomedia) with the characters of Lore and Macu or in movies such as Yo soy la Juani (Bigas Luna, 2006). Amongst all these names, celebrity TV star Belen Esteban can be considered the queen of chonis, the only one to receive academic attention in the enlightening article by Mercè Oliva (2014). Oliva points out to a critical factor for this study when analysing fame as a disciplinary regime: 'There are striking similarities between the discourses of disgust aroused by Belén Esteban and those identified in the UK against working-class female celebrities' (2014: 450).

This article outlines an approximation similar to the study of the sexualization of young underclass women on social media used by Willem, Araüna and Tortajada (2015) focusing on their representation on YouTube through the use of tutorial videos. In this context, we tried to analyse how the image of the young underclass is gendered through ironic beauty tutorials and how these amateur representations collide with or participate in the mainstream images of the choni. This article is divided into three sections. The first section gives a brief overview of the most relevant studies in the United Kingdom about the figure of the chav and provides the analytical tools for the study of the figure of the choni. The second section examines the neo-liberal discourses that are present in the practice of YouTube self-representation, and the third section provides a deep analysis of the presented videos, focusing on the cultural aspects of class depiction and specifically on how young 
appearances seem linked to lifestyle discourses. Furthermore, these authors identified this consumerist turn as a mechanism aimed to reinforce the dogma of neo-liberal free will, related to personal election (of clothes, music) with a negative impact on education:

In some cases, chav was almost described as an identity that you can buy into [...] but at the same time you are not authentic unless you are proper poor, and, of course, it is not a lifestyle they would wish to buy into. The notion that this particular identity position is a choice allows for a 'blame the victim' discourse in which, if children choose to be a chav or a gangster, then it is essentially their own fault if they experience the educational consequences of this' choice'.

(Hollingworth and Williams 2009:477)

With the appearance of free will but working as a system of symbolic domination, another important aspect of the cultural and euphemistic transference of class is the fact that its main function is to impose fixity onto those from whom they [the powerful] draw and claim moral distance' (Skeggs 2004: 4). In other words: some people have the power to play with class references, for instance, mimicking the chav clothes, accent or attitudes, and some people become stuck in that social category.

In reference to the essential reconfiguration of the chav phenomenon as a lifestyle, we have to cite Imogen Tyler (2008), who saw in the social construction of the chav a concentration of 'a series of older stereotypes of the white poor' but with a new emphasis on conspicuous and cheap consumer habits. This idea is developed from Hayward and Yar (2006), who argued that the chav is a consumer-oriented classification, dependent on the withdrawal of working positions as class markers as a result of the crisis of Fordism, of state welfarism and the loss of employment security. Hayward and Yarconsider that nowadays, especially amongst the youth population, consumption and having no occupation are crucial for class belonging. Consumption as a tool for selfand social recognition is also an instrument for pathologization, based on the excessive participation in forms of marked-oriented consumption which are deemed aesthetically impoverished' (2006: 14, original emphasis). For these authors, the signs of the chav's vulgar and excessive consumption aesthetic are their sportswear clothing with eye-catching brandings, their flashy jewellery, their accessories, their drinks and their cosmetics, in the form of'excessive make up, sumbed tans'. These analysts argued that stressing the neo-liberal doctrine of individual choice connected to consumerism is a way not only to disguise social exclusion but to promote conspicuous consumption. Bennett (2013) offers a similar explanation, citing the expression of Bauman (1998) of 'choice incompetence', and linking this aspect with the privatization of the public discourse and with an attempt to depoliticize class differences. Bennet argues that supposed chav attributes 'articulate a semiotics of class while denying that this is about a class at all, saturating the social with personal meanings by recontextualizing public experience in such a way as to suggest that is ultimately the private that matter' (2013:160).

Other branches of chav studies have focused research around the concept of disgust. For instance, Imogen Tyler (2008) has written extensively about the emotional factors of the construction of the social type of the teen pregnant chav mother across different media. There she explains how, in the context of a contemporary culture of consumption, disgust is used by middle-classes 


\section{'CHONISMO': CLASS AS CONSUMPTION}

As long as we consider the choni in the same way as these YouTubers do, as a young subcultural group, we are emphasizing the cultural aspects of class. In doing so, we are taking the analytical position of Lawler (2004), Skeggs (2004) and Hollingworth and Williams (2009), who pointed out that economic status is just one of the defining characteristics of class. This inclusion of social and cultural aspects of class is rooted in an array of contemporary theories, from Erving Goffman's self-representation theory (1999), to Foucauldian biopower (2006), to sign negotiation (Hall 1996), to Bourdieu's concept of habitus (1986a, 1990) and especially cultural capital (1986b). The cultural aspects of the notion of class are essential to the development of the English branch of Cultural Studies and especially to the work of Stuart Hall and the New Left. Particularly important for our analysis is Hall's work, 'A sense of classlessness' (1958), in which he pointed out not only that popular culture can be a potential place of class resistance but also that culture can erode traditional class alliances. For the aims of our investigation, also central is the idea that'class may be grounded within and produced through people's identities and cultural practices, rather than just their occupational backgrounds' (Hollingworth and Williams 2009: 468) and also the affirmation of the sociologist Beverly Skeggs that 'race and class are not just classification or social positions but an amalgam of features of a culture that are read onto bodies as personal dispositions' (2004: 1). For this author, class is not a given condition but a continual production through different practices in a process 'always made by and in the interests of those who have access to power and the circuits of symbolic distribution' (2004: 2)

Skeggs' definition of class formation and class assignation as a dynamic struggle fuelled by symbolic conflict and submitted to a process of 'euphemistic transference' (2004: 5) into objects, dress, behaviours, (gendered and sexed) bodies and other cultural and subcultural markers, such as music (Martinez 2007), is central to contemporary approaches to the chav phenomenon, due to the mechanisms of class displacement and individualization (Lawler 2004). For instance, Hollingworth and Williams in their study of the construction of working class youth as 'others' in three urban state schools of England, concluded that the class rhetoric is transferred to 'music tastes and fashion tastes' (2009: 470). Moreover, they identified the following class features in student discourses which fell into the othering and pathologization of their working-class peers:

Chavs were most commonly defined by their brash and excessive dress and appearance (aesthetic); their careless, unruly and often violent behaviour (performative); and, in the context of schooling, their lack of respect for and disengagement witheducation (moral).

(Hollingworth and Williams 2009:473)

For Hollingworth and Williams the above characteristics are antithetical to the self-regulated, reflexive and autonomous neo-liberal subject, and serve to build an oppositional class place occupied by the middle-class students (normative subjects); but at the same time, their cultural and external 
to 're-demarcate class boundaries' (2008: 22) and block social mobility (2008: 32). Furthermore, for Tyler, the media presence of 'class-naming' is a sign of the obvious re-emergence of class discourses through comical or ironical stereotyping. Since class comedy is 'boundary-forming' and 'creates a distance between 'them' and 'us', disgust creating is not only reactive but 'constitutive of social class' (2008: 23), especially in a context as the United Kingdom where the class inequalities have been substantially increased. In a similar fashion, Jessica Ringrose and Valerie Walkerdine (2008) have studied the figure of the abject working woman in makeover TV shows who'fails as subject/object of desire and consumption, and lacks requisite qualities of self-reflexivity necessary for reinvention' (2008: 228). In this type of reality-show, the working woman is a spectacle of 'physical abjection - disgust and fascination - through which subjects (ourselves and others) become constituted as failing' (2008: 235), in order to highlight personal blame and personal incompetence. Moreover, the show's dynamic of the transformation is never complete due to the absence of cultural, social or symbolic capital related to the middle-classes, but allows spectators to recognize class in these'abject signals which we must not inhabit [...] must identify against' $(2008: 240)$.

\section{YOUTUBE: AUTHENTICITY, GENDER AND NEOLIBERALISM}

The video sharing platform YouTube is one of the most popular websites on the Internet with more than a billion users and 'each day those users watch a billion hours of video' (YouTube Press, 2017). Snickars and Vonderau (2009), in their analysis of YouTube, identify the tension between community and commerce as one of its main characteristic. This aspect is crucial to understanding debates around authenticity in this platform: amateur content is related to the genuineness of video-blogging (vlogging), while corporate content is related to the falseness of economically driven videos, especially music videos (Burgess and Green 2009; Duplantier 2016).

It has been reported (YouTube 2015) that amateur videos are among the most commented videos on YouTube, due to the mechanics of the gaze's interpellation directed to the camera, the conversational style, and, as Burgess and Green argue, "the extensive "spreadability" of the ideas, styles and materials associated with YouTube's homegrown stars' (2009: 100). This view is complemented with Patricia G. Lange's (2009) notion of 'videos of affinity' directed'to maintain feelings of connection with potential others who identify or interpellate themselves as intended viewers of the video' (2009: 71). These informal, personal and often banal kinds of videos are one recurrent tool to maintain an open and active communication with followers and to build an essential sense of grassroots community inside a participatory media like YouTube.

In the visual regime of YouTube, vlogging has achieved a particular domestic and amateur aesthetic and some basic productions values 'structured around a monologue delivered directly to camera' (Burgess and Green 2009: 94). Inside the web's participatory culture, the term tends to be used as a synonym of 'self-expression', with some aspects of the confessional culture inherited from reality TV and, related to youth audiences, with some aspects of visual production from inside the new media landscape of the 'bedroom culture' (Hodkinson and Lincoln 2008; Livingstone 2007). Even though not all vloggers make home-based videos, and despite the presence of a distinctive aesthetic, Burgess and Green argue that there is not such a clear demarcation between amateur and corporate uploaders, referring to 'entrepreneurial 
vloggers' and pointing out that 'the possibilities of inauthentic authenticity are now a part of the cultural repertoire of YouTube' (2009: 95). In the same vein, Jenny Kidd (2016) in her book Representation notes that beauty vloggers on YouTube are'a prime example of how authenticity, self-representation, consumerism and corporate interests are juxtaposed in the social mediascape' (2016: 70), pointing out that beauty vlogging is one of the most popular trends on YouTube.

In her case study of popularity markers in YouTube's attention economy, Florencia García-Rapp (2016: 2) claims that on YouTube, beauty content reached 1.6 billion views in March 2015, with more than 180,000 beauty gurus uploading more than 100 hours of content per day. Furthermore, according to Tianna Fischer (2014), four of the top 100 most subscribed channels on YouTube are beauty vlogs. Apart from this, García-Rapp stress the importance not only of the commercial aspect of beauty tutorials, but also their educational aspects, as there are ideologies of learning and the pedagogical values inherent to this kind of production. This expertise, defined as 'communityspecific know-how', is shown in 'quick, easy-to-follow, music-laden, instructional videos' (2014: 10). For García-Rapp, beauty tutorials are a combination of pedagogical and performative or media aspects, teaching the dynamics of self-construction in an 'active reworking and updating of audience's identities' (2016: 14). On the other hand, Tianna Fischer adds another aspect to the equation of the beauty and fashion tutorials: the show. This refers to the spectacle involved in stressing the aesthetics qualities of everyday practices such as clothing or make-up. For Fischer, citing Lev Manovich, make-up and clothing are part of the industrial toolbox for personal'bricolage, assembly, customization, and [...] remix' (2009: 322). In a similar way, Sandra Weber (Weber and Mitchell 2008), in discussing adolescence as a period of identity formation, largely confirms this point of view by talking about the digital production of the selfhood as 'identity-in-action'. This is a media process by which identities are 'constructed, deconstructed, shaped, tested, and experienced' (2008: 27) and in which 'the identities emerging through multimedia production retain traces of the original material' (2008:39).

In sharp contrast with these postmodern perspectives, we can name classical Foucauldian analyses of techniques to curate the female body used in YouTube tutorials, such as that by Sandra Lee (1997), in which makeup is not a practice of self-expression but of self-discipline. This view of female self-disciplining beauty techniques that, as we suggest, we can find in YouTube tutorials is complemented by the extra surveillance suffered by women YouTubers. Lindsey Wotanis and Laurie McMillan (2014) have shown that'surveillance, judgment, and evaluation' is suffered to a greater extent by female YouTubers than by male participants (2014: 191). The study carried out by Banet-Waiser (2011: 18) about post-feminism on girls' YouTube videos, shows that comments on this kind of media function 'more often than not as a neo-liberal disciplinary strategy, where videos are judged and gain value according to how well the girls producing them fit normative standards of femininity'.

The idea that neo-liberalism is central to the construction of online personalities is also present in the study of Brooke Erin Duffy and Emily Hund (2015) about fashion bloggers. In this article, the authors stressed the importance of self-branding, flexibility and informal knowledges for a post-Fordist economy of consumption, and claim that the form of self-creation and brandladen promotion the fashion bloggers participate ensures that 
they do not deviate too far from their traditional roles as consumer; in so doing, it privileges those with existing economic capital and / or individuals that conform to the aesthetic standards celebrated by mainstream media. These depictions of entrepreneurial femininity are thus inscribed within a culture that constructs women as feminine subjectivities, emotional labourers, and above all, consumers.

(2015: 9)

Talking about everyday practices on YouTube, Banet-Waiser points out that interactive technologies, especially those used by young girls, create a new tool for self-management through which new relationships between young people and corporations are created. This relationship is gendered and is related to post-feminism (McRobbie 2008) in the exercise of self-branding. The ideals of 'capability, empowerment, and imagination' encourage the self-branded girl' to be a product within a neo-liberal context; she authorizes herself to be consumed through her own self-production' (2015: 11, original emphasis). Banet-Waiser argues that YouTube videos do not exist in a vacuum but in close relation to a series of cultural meanings that serve as a validating strategy of a saleable image. Supporting this hypothesis, Alison Hearn (2008: 198) claims that self-branding in social media 'involves the self-conscious construction of a meta-narrative and meta-image of self through the use of cultural meanings and images drawn from the narrative and visual codes of the mainstream culture industries'.

\section{How To Be a choni: VIDEO ANALYSIS}

As we have seen in the previous paragraph, beauty or lifestyle tutorials on YouTube offer an opportunity to think critically about how authenticity is staged, how connections to a potential community are created, how consumerism is important for self-creation techniques and how gender is performed and scrutinized in its relation to the mainstream culture. However, one question that needs to be asked to understand the YouTube narratives around the chon $i$ is how class interacts with all these factors.

For this objective, we opted to apply textual and media analysis (McKee 2003; Bainbridge 2011) to a small but relevant sample of the most viewed YouTube videos related to the subject'How to be a choni'. Our sample included videos by the vlogger Paatristras with 1,112,181 views, by the group of preteen vloggers called Vallintoners with 704,606 views, by the vlogger Sarahhijaputa with 159,978 views and a series by Atun Con Pepitas with 436,407 views for part I, 122,308 views for part II and 66,500 for part III $(893,414$ views in total). All these videos have common characteristics, such as being made by young women, being a parody of the beauty tutorials of YouTube and showing a precise and coincident portrait of the social stereotype of the choni. These YouTube productions are complemented with the video 'Gótica vs. Pija vs. Choni' from the vlogger Rebel, not a beauty tutorial but a representation of the chonis as a youth subculture, with 670,288 views. We have also included three less relevant videos, 'La choni perfecta' by Lorena Gonzalez, a conversional classification of the choni with 32,223 views, and the beauty tutorials of PaZz y Amor with 5850 views and Celia ontheworld with 4685 views, which are used to support different affirmations.

In order to identify the way in which class supports the creation of the choni character, we need to understand the YouTuber's use of class-based 
cultural signs in the construction of this stereotype. We are of the opinion that these videos participate in the contemporary discourses of metaphorical class assignation in their avoidance of direct social naming and their transference to cultural and everyday signs (clothes and make-up). This classic semiotic approach is complemented with the sociological and cultural approach of Beverly Skeggs involving the notion of social belonging, and particularly with her studies about working class women and the 'moral euphemisms'(2005: 965) used to signal and demonize them, especially those related to the construction of the appearance. Skeggs $(1997,2004)$ noted that historically'appearance became the signifier of conduct; to look was to be. The construction of appearance became a cultural property of the person, the means by which women were categorized, know and placed by others' (2004: 99, original emphasis) being the main mechanism for authorization and de-legitimation.

It is interesting to note that the class and gender-based stereotype of the chori has become so fundamental to the Spanish conventional wisdom of the social differences that all the YouTubers employed the same collection of cultural features, a distinctive music, clothes or make-up, almost without variations. This replication can be linked to the reiterated process of Butler's gender performativity in Bodies that matter (1993), where repetition ensures an accurate designation in the production of bodies. For McRobbie, this performativity is understood as 'the reiterative power of discourse to bring into being what it names' (2005: 88). Granting existence to sexed bodies has a significant weight in the studies of girls' culture:'Only by recognising oneself as a girl and taking up the space of designation as girl, can a culturally intelligible speaking subject emerge'. In our analysis, we have divided these repetitive cultural signs into three main categories based on significant schemes of symbolic classification: racialized signs, sexual signs and signs of cultural competence.

In the first place, we are going to analyse the signs that are codified as racial signifiers, namely, the signs connoting or conferring a particular conception of race. The practice of racialization is defined by Amy Ansell as the historical and constructivist 'processes whereby racial meaning is attributed to groups or social practices as a result of which racial hierarchies are constructed, maintained, or challenged' (2013: 217). The racial markers shown in these videos and employed in the construction of the choni take part of what Skeggs identifies as a historical tendency in which 'working-class women were frequently ethicized through assumed sexual profligacy and geographical association with diverse ethnic groups' (2004: 90). But, as Ann McClintock reminds us, the historical process of racialization 'through the equation of dirt, sexuality and blackness' has two main consequences: 'the working-class woman's body was racialized and the middle-class woman whitened' (in Wolkowitz 2001). Added to this, Imogen Tyler (2008: 25) in her study about chavs shows how the mechanisms of racialization and dirt are actively in use in our construction of class, making this sociological group visible:' chavs are not invisible normative whites, but rather hyper-visible "filthy whites"'. For Tyler, this character of 'borderline whiteness' is evident in chav appropriation of black American popular culture'through their clothing, music, and forms of speech'and having 'geographical, familial and sexual intimacy with working-class blacks and Asians and immigrant populations'. This view is supported by Bennet (2003: 149), who suggest that chavs are represented as a white subgroup trying to emulate 'black semiotics practices' in a conservative representational practice designed to diminish 'working-class multiculturalism'. 
Interestingly, in our investigation we discover that racialization is also a feature of the cultural construction of the choni in its direct relationship to Latina and Romani stereotypes. In Veallintoner's video, the association of the choni with young Romani women is built through the use of the flamenco and the use of the word'olé' (01:22). Similarly, in Atun con pepitas'video, chonismo is associated with dancing flamenco and listening to Camela, a famous Spanish pop group with Romani members (00:30, part III) but the association is also visible in the recommendation of using clothes from 'your father, your brother or the "payo"' -'payo' is an untranslatable Romani term used to refer to nonRomanies ${ }^{1}$ (00:05). In Sarahhijaputa's video, the connection with this sociological group is evident in her use of flamenco music and her affirmation that make-up can attract'hottest gypsy guys ${ }^{2}$ (m01:16). In this video, the make-up tutorial is interrupted with mimicked gossip about a friend relating that the other day my friend "la Vane" met a really, really hot gypsy, you know [licking her fingers], ah, payo, with this gypsy I would do a lot of things ${ }^{\prime 3}$ (04:17), making a clear and racialized connection between underclass women and Romani women. Another significant example of this racialization occurs in Rebel's video, when, in introducing the youth subcultures represented in the video - the gothic, the posh and the choni - one of the protagonists suffers a slip of the tongue and improperly announces that the video is going to represent a 'gitana', a'gypsy'. In a similar fashion, the YouTuber Celia ontheworld, talking about the photographic pose of the'duck face' in the pictures uploaded to social media, and especially those uploaded to Tuenti, explains that 'if you don't do the duck face you' re a boring paya' ${ }^{\prime 4}$ (02:49). Tuenti, referred to as' the Spanish Facebook' (Del Giudice et al. 2014: 18) is, according to an article by Garcia-Jimenez et al. (2013), the only significant class difference in the use of social media by Spaniards since it ' is the option most used by the lower class'.

All of these racial marks are appropriately read by the audiences who reflect, with the usual surveillance of women's bodies, their racial anxieties about this kind of representation. In the two most viewed and commented videos, that of Vallintoners (786 comments) and, paradoxically, that of Paatristras (4004 comments), which has no explicit reference to the Romani community, there are a vast number of comments relating choni fashion to young Romani woman. Some participants expressed that the YouTubers fall into the error of confusing choni with Romani, as commenter Juan Antonio Garcia Garcia posted on the Paatristras video, 'rather they are gypsies but do your own thing $\mathrm{xD}^{\prime},{ }^{5}$ or as Alba Diez Ibañez posted on the Vallintoners video, 'they aren't chonis, they are gypsies'. ${ }^{6}$ Others pointed to the social and geographical proximity between chonis and the Roma people (gitanos), especially in the south of Spain, reflecting how the discourses about racial contamination are still relevant. This can be seen in the sentiment endorsed by Alberto González Pueri in the Paatristras channel:

They tend to be miserable in the long run, since many of them end up marrying young, pregnant, without work or future. There are people who study and work to build a better future. But the Chonis with so much partying and so much gipsy-like partying, in the end it catches up with them, and they pay a very high price. In Andalusia they are more concentrated than anywhere else in Spain, or at least, that's what I've seen. ${ }^{\text {? }}$

This extreme Romanophobia and regional hate towards Andalusia is complemented by comments which point out that the semiotic practices of the chonis payooo'.

2. ‘a los gitanos más guapos'.

3. 'el otro día mi amiga la Vane se encontró con un gitano muy guapo, muy guapo, o sea [se chupa los dedos] ay payo que yo con ese gitano haría muchas cosas.

4. 'si no sales con morrito y con cabeza eres una paya aburría'.

5. 'eso mas bien es de gitanas pero tu a tu royo $x D$ '.

6. "eso no son chonis son gitanas'.

7. 'Suelen ser unas desgraciadas a la larga, ya que muchas terminan casándose jóvenes, embarazadas, sin trabajo ni futturo. Hay gente que estudia y trabaja para labrarse un futuro mejor. Pero las chonis con tanta fiesta y tanto gitaneo, al final les pasa factura, $y$ eso tienc un precio muy alto. En Andalucia se concentran más que en cualquier lugar de España, o al menos, eso es lo que he visto'. 
8. 'Los gitanoos han empezadoo la modaa canii i chonii i nosotross los paios lees hemos copiado'

9. 'Esonoesserchoni, estáis representando a las gitanas, $y$ las estáis dejando en ma lugar en todo, así que primero de todo, si es algo dedicado a reírse, informaros bien y no comparéis con favoritismo, porque quien es choni lo es por que quiere, y según esto las estáis dejando en muy mal lugar. Tanto a las gitanas comoalaschonis'.

10. 'esto no es ser chonis esto es como ser gitana. Los consejos estan mal y las chonis escuchan reggueton o electronix y dejar de hacer el tonto $\mathrm{q}$ no dais ni puñetera gracia'.

11. 'Maquillaje,todoel bote, todoel bote... si te miran es bueno... no pasa nada si pareces un gnomo, tú bronceada. tú la mejor'. have been co-opted from the Roma community, as Thelma Serra Vidal points out in her comment on the Paatristras video:'The gypsieeees have starteeeed the cani and choni fashiooon, and we, the payos, we haaave copied them'. ${ }^{8}$ In far fewer instances comments can be found regarding the false assumption between choni and young Roma women, and the negative connotations of this association, as in one by J.D. Henar on the Vallintoners video:

That is not being a choni, you are representing the gypsies, and you are making them look bad in everything, so first of all, if it is something dedicated to laughing, first learn about it and do not compare with favouritism, because whoever is choni is so because she wants to, and according to this you are leaving them in very bad place. Both gypsies and chonis.

There is also another kind of comment concerned with a particular mistake in the portrait of the choni: the use of music. As expressed by one comment signed by alexandra giosanu on the Vallintoners video, 'This is not being choni, this is like being gypsy. The advice is wrong: chonis listen to reggaeton or electronix, so stop making fools of ourselves cause you are not bloody funny'. ${ }^{10}$

This clarification is also useful in the way that it introduces another racialized factor, the vinculation of chonis with young Latinas, particularly in their use of music, reggaeton, and the kind of dance related to this music, perreo, which involves a type of movement marked by its sexual connotations. We can find cultural marks related to young Latinas in Paatristras' video (00:09) while dancing reggaeton music plays in the introduction of the video. Sarahhijaputa uses this kind of music profusely in her video and in the Rebel video the choni character speaks with a strange and thick Cuban accent and dances perreo spasmodically. These kinds of representations are consistent with the narrative of racial contamination, and reflect some trends in Spanish immigration in the feminization of the immigrant population, especially of Ecuadorans and Colombians (Saenz and Murga 2011: 74). It is also in line with the other media portrait of Latinas on American advertizing as a'hypersexual, loud, aggressive and usually young' in a 'woman-as-a-panethnicity trope' (Báez 2009: 259).

Finally, there is another subtle racialized factor: the extensive use of make-up base in almost all of the seven videos included in this article, but in particular in those of PaZz y Amor (02:56), Sarahhijaputa (00:31), Atun Con Pepitas (08:09, part II) and Vallintoners (00:29), where the make-up is so disproportionate that its use may stain other people in a graphic image of racial contamination. Atun Con Pepitas is more extreme in her presentation because, playing with more parodic elements in relation to the construction of the choni but also in relation to tutorial beauty videos, the protagonist explains how to use make-up base to look like a proper young working-class woman with these terms: 'Make-up, the whole tin, the whole tin [...] if they look at you it's good [...] its OK if you look like a goblin, you look tanned, you're the best'."

The spontaneous and playful attitude, which is absent in the rest of videos, derives from the exaggeration of make-up application and results in a kind of 'black-faced' social class where this caricature is taken to the extreme (00:30 part III). By doing so, the YouTuber shows the prevalence of the category of the abject body in the construction of working-class women stereotypes. 


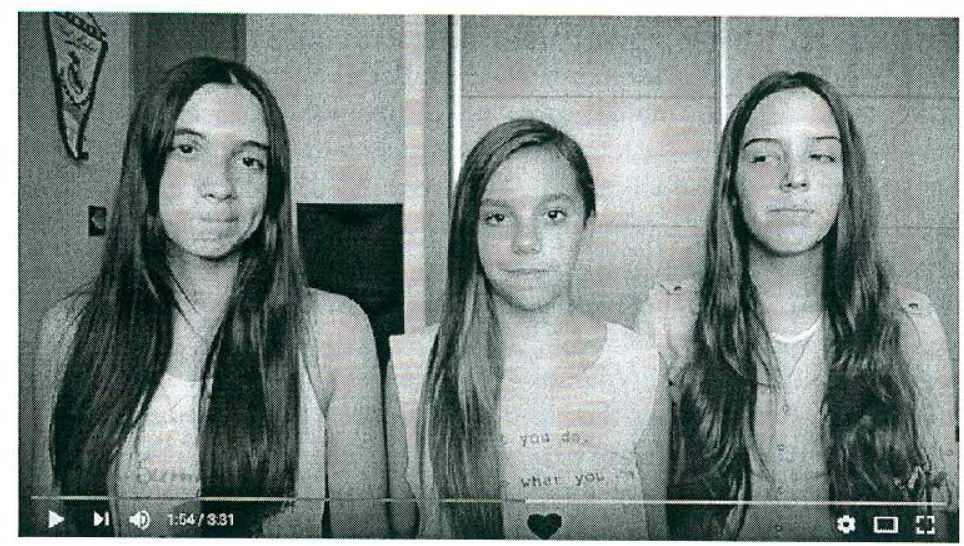

Figure 1: Atun con pepitas (2011), 'Cómo ser la choni perfecta 3/3', Youtube.

Next, we analyse the display of sexual markers in our collection of videos and we are going to subdivide them into three categories: body language, clothing and sexual narratives.

Body language, as a key factor of appearance, is the privileged arena for linking young working-class women with excess and sexuality. Skeggs (2005: 99) notes that the mere attention to one's appearance is seen as sign of 'sexuality in excess', and, in a Foucauldian way, Kathleen Rowe points that 'social groups exercise control over their members by inscribing standards of beauty and perfection, of social and sexual "normalcy," on their bodies' (1995: 62). This raises the question of whether body language is defined by its relationship to the social group. For Rowe, the categories applied to distinct body language categories are interconnected with positions of power: among the powerful, relaxation means 'ease', but for those in need of social control it means 'looseness' or'sloppiness'. For Rowe, the body that refuses to be aestheticized is grotesque and offensive, and can 'communicate resistance to social discipline' and among this opposition 'women of ill-repute, whether fat or thin, are described as "loose", their bodies, especially their sexuality, seen as out of control'. In addition to this, Rowe explains that the body of working-class women is related in the social narratives of the powerful with the realm of bodily functions, the body's expulsions and leakages, signifying 'lack of discipline and self-control' (Skeggs 2004: 102) and more generally with an excess of bodily materiality.

In accordance with these theories, the main tools for communicating sexual excess through the body in these videos are the sexualized positions and dance in the video by Paatristras (00:11) the display of her cleavage (01:55). The out-of-control sexual dance in the Rebel video (02:11) and the body positions in that of Atun Con Pepitas (particularly 01:13, part II and 01:46, part III). Along with these descriptions there is another surprising factor in the construction of the sexual excess of the choni: open-mouth chewing. We can find this item in the Vallintoners video (01:56), in the Rebel video (00:10), in the Lorena Gonzalez video (02:32) and in the Paatristras video (01:22). In the latter two videos, the YouTubers connect this habit directly with prostitution. Paatristras notes that'another very important thing is the chewing gum [...] 
12. 'Otra cosa muy importante es el chicle [...] esto es similara las putas'.

13. ' $Y$ el chicle en la boca.. eso que es similar a las putas, pero no importa'.

14. 'Muysexyasívienen muchos chicos a por mí[...] ¿entiendes? Eso es lo importante... que todos los tíos vengan hacia mi... para eso ves el video, para aprender a que todos los tíos vayan hacia ti y así tienes tracatracatraca [...]'. this is similar to the whores', ${ }^{12}$ and Lorena Gonzalez points that 'And the gum in the mouth [...] that's similar to whores, but it does not matter'. ${ }^{13}$ This relation is not only based in the metaphorical proximity of the voracious women's mouth with sexuality (Bordo 2000) but has historical roots in the history of chewing gum, the tzictli, which was only chewed in public by the prostitutes (Vázquez 1999), showing that the contemporary construction of the body as a symbol of class has enigmatichistorical sources.

Clothing is another definitive factor in the construction of the body of the choni as sexually unruly, as long as 'objects of clothing became invested with intangible and abstract elements of the moral and social order' (Skeggs 2005: 99). For these YouTubers, the clothing selection of the choni represents her sexual availability in their use of bare-midriff, tight or low-cut blouses or pants, spandex or spaghetti strap. These are pieces of clothing that are sexually charged in the way they expose and do not hide the body. This kind of description is used in the Paatristras video (00:18) in the context of talking about a T-shirt that shows the lorzas, a word that can be translated as' pin tucks'but in its popular use is more related to 'fat roll', denoting a fat body out of control. Paatristras also talks about the necessity of revealing sexy underwear, meaning the thread thong underwear or the bra (01:55). We can find recommendations of shorts, tank tops or underwear in almost all the videos. Another factor found in all the videos of our study involved sexualizing subjects through the wardrobe is the use of animal print, an aesthetic election that we can analyse in relation to the racialization process. Several studies have shown that, for instance, the use of animal print in advertizing that features African American women reinforces the stereotype that they 'are animalistic in nature, sexually active, less educated, have lower income, and extremely concerned with personal appearances' (Scott and Dominique 1997).

These basic elements of representation are complemented only in Sarahhijaputa's video with a sexual narrative to emphasize the sexual promiscuity of the choni, the only one found in our collection. Talking about the effects of her make-up the vlogger relates:

Very sexy so many guys come to me $[\ldots]$ do you understand? That's the important thing $[\ldots]$ that all the guys come to me $[\ldots]$ that is why you watch the video, to learn how to attract all the guys and have tracatracatraca $[\ldots] .^{14}$

The lack of sexual narratives can be explained because tutorial videos are based on outward appearance and because they avoid direct enunciation of moral values. Despite this, we can appreciate a common denunciation of hypersexualization in relation to the slut stigma common on social media (Willem et al. forthcoming). Related to that, Armstrong et al. pointed out that women's participation in slut shaming 'is about drawing class-based moral boundaries that simultaneously organize sexual behaviour and gender presentation [...]. Highstatus women employ slut discourse to assert class advantage, defining their styles of femininity and approaches to sexuality as classy rather than trashy' (2014: 101). This way of sanctioning gender performance acceptably, rather than the private sexual life of other women, is a disciplinary social method as long as the social differences are read as sexual differences (Ortner 2006: 34). As we can see in 'How to be a choni', 'women use slut discourse to support status distinctions that are, in this case, linked closely to social class' (Amstrong 2014: 104). 
Finally, we analyse the signs of cultural competence. In these videos, the most common of the cultural markers that talks about the social ineptitude of the choni is the conspicuous and cheap consumer habits related to make-up products. This factor is important because teaching viewers how to consume make-up products is one of the main objectives of beauty tutorials, so using cheap or even free samplers of mascara or lipstick is part of the ironic devices used to subvert this YouTube genre. The condemnation for consuming cheap beauty products is unanimous and unequivocal but is particularly used in the video by Paatristras: 'We need an eyeliner [...] best if it is from the pound shop ${ }^{15}[\ldots]$ and an eye shadow of Bravo [famous Spanish teen magazine] of ten centuries ago'.This aspect is also emphasized several times in Sarahhijaputa's video talking about beauty products:'Now I'm going to put on the mascara, the cheapest I've found' (06:57), 'from the pound shop, from the Bravo, Superpop [another teen magazine], wherever but the cheapest'16 (03:40). Actually, Sarahhijaputa constructs all of her choni character around the lack of knowledge and understanding of beauty techniques, and she repeats and underscores her ineffectiveness in naming or using the products with affirmations such as 'What's its name? I don't care, it's from the pound shop' (01:37) and ' $I$ ' $m$ out of the blue, $I^{\prime} m$ doing my own fucking thing ${ }^{17}(11: 32$, and also in $03: 25$ and $06: 15$ ).

This lack of consumption competence is also reflected in the wardrobe of the chonis, which is full of basic and cheap clothing items as leggings or jackets (Paatristras, 2012: 01:22; Sarahhijaputa, 2014: 09:25), the flashy use of animal print (Paatristras, 2012: 01:17; Sarahhijaputa, 2014: 09:30; Atun Con Pepitas, 2011: 00:56, part I), the overuse of accessories, especially of bags and big hoop earrings (Paatristras, 2012: 01:16; Vallintoners, 2013: 01:40), the ostentatious brands, especially Adidas (Vallintoners, 2013: 01:45; Sarahhijaputa, 2014: 09:35; Lorena Gonzalez, 2016: 00:55), the love for high heels or a particular type of shoes (Victoria and Mustang for Atun Con Pepitas, 2011: 01:54, part I, and wedge heel for Sarahhijaputa, 2011: 09:25) or any item or material that transmits a fake fashion aura, like fake plastic glasses or a fake'I Love NYC' T-Shirt in Atun Con Pepitas. This artificiality is complemented by the habit of painting fake facial piercings with the help of eyeliner, as we can find in videos by Sarahhijaputa (12:35), Atun Con Pepitas (00:30, part III), Lorena Gonzalez (00:41), Vallintoners (01:06) and Paatristras (01:09). We can read these inauthentic fashion marks in relation to the cultural concept of natural beauty as a bourgeois ideal of attractiveness, which for Skeggs (2005: 100) is related to the occultation of beauty labour. Talking about excessively styled hair, something also present in these videos, Skeggs explains that'the binary between nature/ artifice is mapped through hidden/apparent labour, read on the body through appearance'. The obviously produced look of the choni takes part in this natu$\mathrm{ral} /$ artificial dialectic, making apparent the relationship of the working-class women with beauty labour and its fabricated character that can be easily replicated or mimicked on YouTube.

Finally, we conclude our analysis of the videos talking briefly about broader cultural markers such as the grammar, syntax, semantics, idioms and pronunciation used in the construction of the choni, which generally refer to poorly educated women in their exclusion of letters ('comío' for' comido'), their mispronunciation of beauty products ('airliner' for' eyeliner') and their informal writing. Atun Con Pepitas commits part of her analysis of chonis' manners to the kind of writing used in social media statuses, particularly those posted on Tuenti and their unjustified iteration of vowels, but this analysis is beyond
15. The pound shops or discount variety stores in Spain are racialized as 'Chinese shops' (01:01)

16. 'ahora me voy a poner la máscara, la más barata que he encontrado' / de los chinos, de la Bravo, del Superpop o de lo que sea, de lo más barato'.

17. ¿Cómosellama? Qué más da, me lo compré en los chinos'/ "que no me entero que yo lo hago a mi puto mundo' 

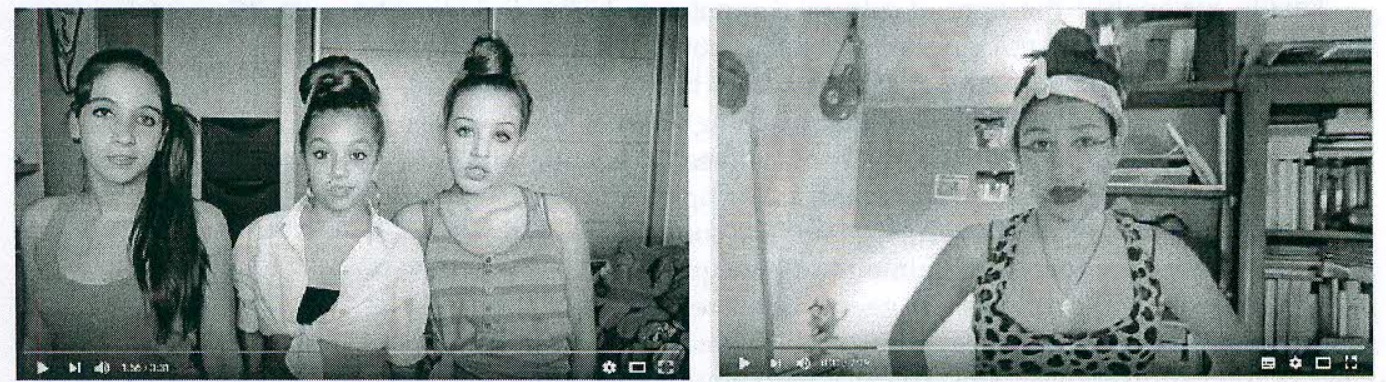

Figures 2 and 3: Vallintoners (2013), 'Aprende a ser la choni perfecta', Youtube.

the goals of this article. Curiously enough, according to these videos the only cultural competence allowable for the chonis is their mastery and control of self-representation in social media, and particularly on their Tuenti profile; however, this capacity is dismissed again as an opportunity for self-sexualization, as they strike a pose and make duck face.

\section{CONCLUSIONS}

Our analysis of YouTube videos related to the construction of the choni has led us to conclude that, similar to the formulation of the English chav, in the Spanish recession the othering of lower social classes is built around a chain of signs of symbolic domination. These signs are at the same time a recrudescence and a displacement of the traditional discourses around social class, in a 'euphemistic transference' of music, clothing, gendered bodies and especially cheap and conspicuous consumption, and are based in the classic Bourdieuan definition that tastes 'function as markers of "class"' (Bourdieu 1986a: 2). For Bourdieu, taste

functions as a sort of social orientation, a 'sense of one's place', guiding the occupants of a given place in social space towards the social positions adjusted to their properties, and towards the practices or goods which befit the occupants of that position.

(1986a: 466)

This construction of social class as a lifestyle or as fashion highlights how the neo-liberal discourses of the privatization of social class differences and the personal responsibility of poverty, disguised as 'choice incompetence', have succeeded in a country facing a dramatic economic crisis.

These videos are also an important cultural indicator of the beliefs of the middle classes in Spain and their fear of being confused with the lower classes, displayed in the way they create a recognizable stereotype, the choni. Skeggs, citing Homi Bhabba, explains how'the real problem of differentiation in the contemporary is not distance but proximity. The problem is of perceived similitude by those who feel to close' (2005: 96). During the economic crisis in Spain, where over three million people have been expelled from the middle classes (Estefanía 2016; Gómez 2016; Tairi 2016), this sensation of closeness is overwhelming and the visual and rhetoric devices used in these videos serve not only to impose fixity on the chonis but to exercise by the vloggers the required self-reflexivity to succeed in a neo-liberal system. 
In addition to this, we can consider these videos as tools for social 'othering'. As Schwalbe et al. (2000: 422) suggest, othering is a process of creating and reproducing inequality where a dominant group redefines an inferior group. Among the forms that othering can take, one that is particularly relevant to the discourses about the choni is the 'defensive othering' as 'identity work done by those seeking membership in a dominant group'. This adaptive reaction of accepting the legitimacy of the social stigma of your own group but distancing oneself from it, of othering your own people (young women in this case) is part of a larger social differentiation process between the so-called middle classes and the underclasses, and is particularly relevant in the Spanish society after the economic crisis.

This article has highlighted the way this self-reflexivity is trained in a platform such as YouTube, where the notion of authenticity is blurred and where the entrepreneurial dogma is present. These findings have confirmed the idea of the'spreadability' of the ideas (Burgess and Green 2009) used by the vloggers, social class being one of the most powerful. We have proven how the banal, personal and informal characteristics of the videos can create a feeling of affinity, which can also be considered as a social class affinity. This mood is reinforced by the class-comedy on display in the videos that helps to create a bond and, as Taylor notes, is constitutive of social class.

The self-reflexivity shown in these videos is, as we have described, especially fruitful in beauty tutorials where the pedagogical and performative aspects of the teaching processes allow different degrees of self-construction or self-branding. The process of identity construction through YouTube is built on media materials and is crossed by social and economic positions; the choni, lacking of flexibility, informal knowledge or even access to the technology, is the fixed and pathologized Other that can be imitated. The vlogger has the capacity to enter and exit from this character, and in this process they can prove their consumer skills and make evident the disciplinary elements related to beauty techniques (hair, make-up, body language). In this social class surveillance and beauty discipline regime, as in Victorian conduct manuals, the representation of normative bodies, clothes and attitudes is reinforced.

Finally, the evidence from this study suggests that the figure of the choni as created by these vloggers is a racialized one, with clear connections with the Romani community and young Latinas. In this process of racialization and ethnizitation, the choni appears in relation to dirt and sexuality, showing a peripheral whiteness of appearance that seems more authentic and enjoyable in the game of self-construction and self-differentiation on YouTube. The character of the choni is also hyper-sexualized in her excess of bodily materiality and her use of wardrobe. Hypersexualization is also linked to the 'slut shaming' process by which class differentiations are reinforced. Furthermore, showing her association with the chavette, the choni is a culturally incompetent character in her cheap habits of consumption, in her fabricated looks that display the labour implicit in feminine beauty and in her lack of proper cultural markings.

Taken together, these findings suggest a renovation of the unexpired Spanish's class differentiation mechanisms towards a new visual and gender regimen, which puts again at the heart of the public debate the figure of the young underclass woman who concentrates all the social anxieties of a country living one of the deepest economic and social crisis of its history. 


\section{references}

Aída (2005-2014, Spain: Telecinco).

Álvarez, P. (2015), 'Spanish youths take longer than average to find first job', El País, 22 September, https://elpais.com/elpais/2015/09/22/ inenglish/1442915877_117797.html . Accessed 1 October 2017.

Ansell, A. (2013), Race and Ethnicity: The Key Concepts (Routledge Key Guides), New York: Routledge.

Armstrong, E. A., Hamilton, L. T., Armstrong, E. M. and Seeley, J. L. (2014), 'Good girls: Gender, social class, and slut discourse on campus', Social Psychology Quarterly: American Sociological Association, 77:2, pp.100-22.

Atun Con Pepitas (2011), 'Cómo ser la choni perfecta', YouTube, ttps: / / www. youtube.com/watch?v=09WqpQN7Fuk, https://www.youtube.com/watch? $\mathrm{v}=$ Yq2Rn36vspk, https://www.youtube.com/watch? $\mathrm{v}=\mathrm{HjPiA8eUmV8}$. Accessed 1 October 2017.

Báez, J. M. (2009), 'Mexican (American) women talk back: Audience responses to Latinidad in U.S. advertising', in A. N. Valdivia (ed.), Latina/o Communication Studies Today, New York: Peter Lang, pp. 257-83.

Bainbridge, J. (2011), 'Textual analysis and media research', in J. Bainbridge, N. Goc and E. Tynan (eds), Media \& Journalism: New Approaches to Theory and Practice, Melbourne: Oxford University Press, pp. 229-43.

Banet-Waiser, S. (2011), 'Branding the post-feminist self: Girls' video production and YouTube', in M. C. Kearney (ed.), Mediated Girlhoods: New Explorations of Girls' Media Culture, New York: Peter Lang, pp. 277-93.

Bauman, Z. (1998), Work, Consumerism and the New Poor, Maidenhead: Open University Press.

Bennett, J. (2013), 'Chav-spotting in Britain: The representation of social class as private choice', Social Semiotics, 23:1, pp. 146-62.

Bordo, S. (2000),'Hunger as ideology', in J. B. Schor (ed.), The Consumer Society Reader, New York: The New Press, pp. 99-117.

Bourdieu, P.(1986a), Distinction, London: Routledge and Kegan Paul.

- (1986b), 'The forms of capital', in J. Richardson (ed.), Handbook of Theory and Research for the Sociology of Education, New York: Greenwood, pp. 241-58.

(1990), The Logic of Practice, Cambridge: Polity.

Burgess, J. and Green, J. (2009), 'The entrepreneurial vlogger: Participatory culture beyond the professional-amateur divide', in P. Snickars and P.Vonderau (eds), The YouTube Reader, Stockholm: KB, pp. 89-108.

Butler, J. (1990), Gender Trouble. Feminism and the Subversion of Identity, London: Routledge.

- (1993), Bodies That Matter, New York: Routledge.

Celia ontheworld (2014), 'como ser una choni $={ }^{* \prime}$, YouTube, https: / / www. youtube.com/watch?v=_krZpEkZZI4 . Accessed 1 October 2017.

Cerro, R. (2014), 'Chonis y poligoneras', Blogs ABC, http:// abcblogs.abc.es/ pienso-de-que/2014/04/19/chonis-y-poligoneras /.Accessed 19April 2014.

Del Giudice, M., Della Peruta, M. R. and Carayannis, E. G. (2014), Social Media and Emerging Economies, New York: Springer.

Duffy, B. E. and Hund, E. (2015), "'Having it All" on social media: Entrepreneurial femininity and self-branding among fashion bloggers', Social Media + Society, 1:2, 2015, pp. 1-11.

Duplantier, A. (2016), Authenticity and How We Fake It: Belief and Subjectivity in Reality TV, Facebook and You Tube, Jefferson, NC: McFarland \& Company, Inc. 
Eco, U. (1983), 'TV: La transparenza perduta', in U. Eco, Sette anni desiderio, Milano: BompianiSrumenti, pp.163-79.

Estefanía, J. (2016), 'No es la clase media; es la clase baja', El País, 10 May, http://economia.elpais.com/economia/2016/05/09/actualidad/ 1462777194_298235.html. Accessed 1 October 2017.

Fischer, T. (2014), 'Makeup, YouTube, and amateur media in the twenty-first century', Crash/Cut Undergraduate Film Journal, 3: Winter, https: / / commfilm.ucalgary.ca/filmsociety/sites/commfilm.ucalgary.ca.filmsociety/files/c rashcut_3.pdf.Accessed 1October 2017.

Flavor of Love: Charm School (2007, USA:VHI).

Foucault, M. (2006), The Will to Knowledge (Vol. 1), London: Penguin Books.

Gandia Shore (2012-2013, Spain: MTV España).

García-Jiménez, A., López de Ayala-López, M. C. and Catalina-García, B. (2013), 'The influence of social networks on the adolescents' online practices', Comunicar Journal, 41:21, pp. 195-204.

Garcia-Rapp, F. (2016), 'Popularity markers on YouTube's attention economy: The case of Bubzbeauty', Celebrity Studies, 8:2, pp. 228-45, http:/ / dx.doi. org / 10.1080/19392397.2016.1242430. Accessed 1 October 2017.

Goffman, E. (1999), The Presentation of Self in Everyday, Massachusetts: Peter Smith Publisher.

Gonzalez. L. (2016), 'La choni perfecta', YouTube, https:/ / www.youtube.com/ watch?v=OGEt_fL9nRE. Accessed 1 October 2017.

Gómez, M.V. (2016), 'La clase media pierde tres millones de personas por la crisis', El País, 7 May, http:/ / economia.elpais.com/economia/2016/05/06/ actualidad/1462546931_374620.html. Accessed 7 May 2016.

Hall, S. (1958), 'Sense of classlessness', Universities and Left Review, 5, pp. 26-32.

- (1996), Critical Dialogues in Cultural Studies, London: Routledge.

Hayward, K. and Yar, M. (2006), 'The chav phenomenon: Consumption, media and the construction of the new underclass', Crime Media Culture, 2:1, pp. 9-28.

Hearn, A. (2008), "'Meat, Mask, Burden" probing the contours of the branded "self"', Journal of Consumer Culture, 8:2, pp.197-217.

Hodkinson, P. and Lincoln, S. (2008), 'Online journals as virtual bedrooms? Young people, identity and personal space', YOUNG - Nordic Journal of Youth Research, 16:1, pp. 27-46.

Hollingworth, S. and Williams, K. (2009), 'Constructions of the working-class "Other" among urban, white, middleclass youth: "Chavs", subculture and the valuing of education', Journal of Youth Studies, 12:5, pp. 467-82.

Jones, O. (2012), Chavs, the Demonization of the Working Class, London: Verso.

Kidd, J. (2016), Representation, Key Ideas in Media and Cultural Studies, New York: Routledge.

Lange, P. (2009), 'Videos of affinity on YouTube', in P.Snickars and P.Vonderau (eds), The YouTube Reader, Stockholm: KB, pp. 70-88.

Las Joyas de la Corona (2010, Spain: Telecinco).

Lawler, S. (2004), 'Rules of engagement: Habitus, power and resistance', The Sociological Review, 52:2, pp.110-28.

Lee, S. (1997), 'Foucault, femininity, and the modernization of patriarchal power', in S. Lee, Femininity and Domination, London: Routledge, pp.63-83.

Livingstone, S. (2007), 'From family television to bedroom culture: young people's media at home', in Eoin Devereux (ed.), Media Studies: Key Issues and Debates, London: SAGE Publications, pp.302-21. 
Luna, B. (2006), Yosoy la Juani, Barcelona: Media Films.

Manovich, L. (2009), 'The practice of everyday (media) life: From mass consumption to mass cultural production?', Critical Inquiry, 35:2, Winter, pp.319-31.

Martinez, R. (2007), 'Taste in music as a cultural production: Young people, musical geographies and the imbrication of social hierarchies in Birmingham and Barcelona', Ph.D. thesis, Bellaterra: Universitat Autònoma de Barcelona.

McKee, A. (2003), Textual Analysis, London: SAGE.

McRobbie, A. (2005), The Uses of Cultural Studies, London: SAGE.

- (2008), The Aftermath of Feminism: Gender, Culture and Social Change, London:SAGE.

Princesas del barrio (2011, Spain: laSexta).

Mujeres y hombres y viceversa (2008-present, Spain: Telecinco).

Oliva, M. (2014), 'Celebrity, class and gender in Spain: An analysis of Belén Esteban's image', Celebrity Studies, 5:4, pp. 438-54.

Ortner, S. (2006), Anthropology and Social Theory: Culture, Power, and the Acting Subject, London: Duke University Press.

Paatristras (2012), 'Cómo ser una choni', YouTube, https://www.youtube.com/

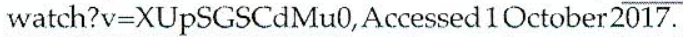

PaZz y Amor (2013), 'Cómo ser "Choni" (Intento fallido)', YouTube, https: / / www.youtube.com/watch?v=Vnoy1KTES6Q. Accessed 1 October 2017.

Rebel (2016), 'Gótica vs. Pija vs. Choni', YouTube, https://www.youtube.com/ watch?v=6hj2gyCtF-A.Accessed 1 October 2017.

Ríos, F. (2014), 'Las chonis', La Voz de Galicia, 3 May, http: / / www.lavozdegalicia.es/noticia/opinion/2014/05/03/chonis/0003_201405G3P17994.htm. Accessed 3 May 2014.

Ringrose, J. and Walkerdine, V. (2008), 'Regulating the abject', Feminist Media Studies, 8:3, pp. 227-46.

Rowe, K. (1995), The Unruly Woman: Gender and the Genres of Laughter, Austin: University of Texas Press

Saenz, R. and Murga, A. L. (2011), Latino Issues: A Reference Handbook, Santa Barbara: ABC-CLIO.

Sarahhijaputa (2014), 'Como ser una choni (maquillaje)', YouTube, https:// www.youtube.com/watch?v=5J7cq8_ZWgw. Accessed 1 October 2017.

Schwalbe, M., Godwin, S., Holden, D., Schrock, D., Shealy, T. and Wolkomir, M. (2000), 'Generic Processes in the Reproduction of Inequality: An Interactionist Analysis', Social Forces, 79:2, pp.419-52.

Scolari, C. (2008), 'This is the end: Las interminables discusiones sobre el fin de la televisión', La Trama de la Comunicación, 13, pp. 13-25.

Scott, P. and Dominique, N. (1997), 'Racial and gender biases in magazine advertising: A content-analytic study', Psychology of Women Quarterly, 21:4, pp. 627-44.

Serrano, A. and Martín, P. (2017), 'From “Employab-ility" to "Entrepreneuriality" in Spain: Youth in the spotlight in times of crisis', Journal of Youth Studies, 20:7, pp.798-821.

Skeggs, B. (1997), Formations of Class and Gender, Becoming Respectable, London: SAGE.

(2004), Class, Self, Culture, London: Routledge, Kindle Edition.

- (2005), "The making of class and gender through visualizing moral subject', Sociology, 39:5, pp. 965-82.

Snickars, P. and Vonderau, P.(2009), The YouTube Reader, Stockholm: KB. 

Tairi, J. (2016),'La crisis expulsa de la clase media a tres millones de españoles', ABC, 6 May, http://www.abc.es/economia/abci-clase-media-espanolaperdido-3-millones-personas-durante-crisis-201605061231_noticia.html. Accessed 14 April 2016.

Trapiello, R. (2009),'Chonis', La Nueva España, 6 November, http:/ / www.lne. es/opinion/2009/11/06/ chonis/830629.html. Accessed 6 November 2009.

Tyler, I. (2008), 'CHAV MUM CHAV SCUM class disgust in contemporary Britain', Feminist Media Studies, 8:1, pp. 17-34.

Tyler, I. and Benett, J. (2009), 'Celebrity Chav: Fame, femininity and social class' draft', Lancaster: Department of Sociology, Lancaster University, http: / / www.lancs.ac.uk/fass/sociology/papers/tyler-whitetrashcelebrity.pdf. Accessed 1 October 2017.

Vallintoners (2013), 'A prende a ser la choni perfecta', YouTube, https: / / www. youtube.com/watch?v=Be0Iqs7qY5w. Accessed 1 October 2017.

Vázquez, G. (1999), 'El milagro del chicle: De cómo la negra e insípida goma que masticaban las prostitutas aztecas se convirtió en una afición universal', La Aventura de la Historia, 1:3, pp. 78-80.

Weber, S. and Mitchell, C. (2008), 'Imagining, keyboarding, and posting identities: Young people and new media technologies', in D. Buckingham (ed), Youth, Identity, and Digital Media, Cambridge, MA: The MIT Press, pp. 25-48.

Willem, C., Araüna, N. and Tortajada, I. (2015),'Slut-shaming on social networking sites among Spanish youth', paper presented at ECREA off-event 'Media (in)visibility: Gen-der and sexual diversity in European popular media culture', ECREA Gender \& Communication Section, Tarragona, October 2015

- (forthcoming), 'Chonis and pijas. Slut-shaming and double standards in online performances among Spanish teens', Sexualities, n.pag.

Wolkowitz, C. (2001), 'The working body as sign: Historical snapshots', in K. Backett-Milburn and L. Mc Kie (eds), Constructing Gendered Bodies, New YorkCity: Palgrave, pp. 85-104.

Wotanis, L. and McMillan, L. (2014), 'Performing gender on YouTube', Feminist Media Studies, 14:6, pp. 912-28.

Youtube Press (2017), 'YouTube for Press', https://www.youtube.com/intl/ en-GB/yt/about/press/. Accessed 1 October 2017. 